\title{
The Impact of Contextualizing Board Structure on Firm Financial Performance in an Emerging Market
}

\author{
Madi M Almadi \\ RMIT University \\ E-Mail: madi.almadi@rmit.edu.au
}

\begin{abstract}
The impact of the emerging markets context has been largely neglected in mainstream corporate governance research. The purpose of this paper is to conduct the first empirical study that investigates the relationship between board structure and firm financial performance through bundling theory with contextual considerations for economic, political, and social elements of the emerging Saudi Arabian market. This study uses archival data from a longitudinal sample of all listed firms in the Saudi market for years 2009 to 2013, taking into account the risks of endogeneity bias to OLS regression. The paper found that outside directors from a privileged regional background and government representative directors on the board of companies predict a better return on assets, while outside directors from the ruling royal family positively influence corporate performance only when they are joined by government representative directors. Integration between theory and context provided a more accurate diagnosis of board phenomena in Saudi Arabia. Optimising the recognition of board members by utilising informal institutions determines the actual boardroom players who influence firm profitability. Such an approach involves significant implications for corporate governance theories and practices. Whether this holds in the context of other emerging markets is an area worthy of further investigation.
\end{abstract}

Keywords: Board Structure, Contextual Consideration, Firm Financial Performance, Emerging Markets, Saudi Arabia

\section{INTRODUCTION}

Board structure has a substantial influence on the practice of corporate governance in advanced markets as well as in emerging markets (Allen, 2005; Marquis \& Raynard, 2015). Recent research indicates that the significance of board structure not only arises from managerial scandals and corporate collapse, but also from its impact on firm 
financial performance. Specifically, numerous empirical studies reveal that certain structural approaches in board structure enhance firm financial performance (Payne, Benson, \& Finegold, 2009). While these studies made a significant contribution to theory and practice, they have predominantly been developed within the context of an advanced market. Given that the underpinning theories used by these studies have originated from a mature market with well-established institutions, the applicability of their findings in an emerging market context is questionable. Indeed, Fan, Wei and Xu (2011) and Xu and Meyer (2013) claim that relying merely on the Anglo-Saxon board classifications (independent, outside, and inside) seems counterintuitive when investigating the financial implications of board structure in emerging markets without considering their significant contextual implications, given that boardrooms in those markets are highly populated by influential families and government representatives, who in turn represent the actual players on the board.

Despite recent attempts to recognize the pivotality of context when determining the effect of board structure on firm financial performance in emerging markets, Judge (2012) and Marquis and Raynard (2015) clarify that the majority of research has largely neglected bundling the contextual considerations of emerging markets with theory. Schiehll, Ahmadjian, and Filatotchev (2014) explain that theory-context bundling involves configurations of governance mechanisms in emerging markets that simultaneously operate at the national level to govern firms within an overall economy or collection of economies. According to Huse, Hoskisson, Zattoni, and Vigano (2011: 12), accurate understanding of the relationship between board structure and firm financial performance in emerging markets 'requires an explicit involvement of context'. This signifies that an analysis of the phenomenon of board structure in emerging markets without the integration of theory and context lacks precision.

Furthermore, as the bundling approach is a relatively recent trend among researchers, empirical evidence still remains relatively scarce (Kearney, 2012; Schiehll et al., 2014; Xu \& Meyer, 2013; Young et al., 2008), and in some contexts this approach is completely unrepresented, as is the case in Saudi Arabia. In this regard, this paper aims to address the aforementioned issue, utilizing an integration of agency theory and class hegemony theory (Daily, Dalton, \& Cannella, 2003) in the context of the emerging Saudi Arabian market. Particularly, this paper will identify the key social, political, and administrative Saudi players who populate the boardrooms and empirically examine their effectiveness in influencing firm financial performance in Saudi Arabia. In doing so, this paper answers the following questions: who actually populates Saudi boardrooms, and how effective is their board deliberation in relation to corporate financial outcomes? Correspondingly, the contributions of this paper lie in the provision 
of a more comprehensive theoretical approach and within the statistical findings in the context of an important emerging market. The rest of this paper is arranged as follows: firstly, the paper provides background on the context of the emerging Saudi Arabian market. It then builds on this discussion to develop theoretical arguments. This is followed by a presentation of the research methods applied. Finally, the paper discusses the results and provides avenues for future research.

\section{The Context of the Emerging Saudi Arabian Market}

Saudi Arabia is a vibrant country with an emerging stock market known as Tadawul. Table 1 provides an overview of some of the major insights of the Saudi Arabian economy and market.

Table 1 Insights for the Saudi Arabian Economy and Tadawul*

\begin{tabular}{lcccccccccc}
\hline & 2004 & 2005 & 2006 & 2007 & 2008 & 2009 & 2010 & 2011 & 2012 & 2013 \\
\hline GDP at Current Prices (m) & 250,347 & 315,333 & 356,160 & 381,467 & 468,800 & 429,093 & 526,800 & 669,520 & 711,040 & 748,448 \\
Debt to GDP \% & 11.4 & 18.4 & 21.0 & 12.3 & 33.0 & 14.0 & 8.5 & 5.4 & 3.7 & 2.7 \\
Inflation \% (Consumer Prices) & 0.3 & 0.7 & 2.2 & 4.1 & 9.9 & 4.1 & 3.8 & 3.7 & 2.9 & 3.5 \\
Foreign Exchange Reserves, & & & & & & & & & & \\
Including Gold (m) & 29,304 & 157,387 & 228,957 & 309,287 & 451,279 & 420,984 & 459,313 & 556,571 & 673,740 & 737,797 \\
FDI Inflow (m) & -334 & 12,107 & 17,140 & 22,821 & 38,151 & 32,100 & 28,105 & 16,400 & 13,732 & 9,298 \\
FDI Outflow (m) & 300 & -350 & -48 & -135 & 3,498 & 2,177 & 3,907 & 3,442 & 3,333 & 4,443 \\
FDI Net Inflows (\% of GDP) & -0.1 & 3.7 & 4.9 & 5.9 & 7.6 & 8.5 & 5.5 & 2.4 & 1.7 & 1.2 \\
Population (m) & 22.68 & 23.21 & 24.04 & 24.8 & 25.5 & 26.17 & 26.81 & 27.45 & 28.08 & 29.99 \\
Unemployment \% & 11.0 & 11.5 & 12.0 & 11.0 & 9.8 & 10.5 & 10.0 & 12.4 & 12.1 & 11.7 \\
Number of Listed Firms & 73 & 77 & 86 & 111 & 126 & 135 & 146 & 150 & 158 & 161 \\
Market Value (m) & 306,293 & 650,176 & 326,896 & 519,040 & 246,533 & 318,800 & 353,440 & 338,880 & 373,413 & 467,467 \\
Number of Investors (m) & 1.38 & 2.57 & 3.58 & 3.67 & 3.80 & 3.99 & 4.05 & 4.10 & 4.22 & 4.34 \\
Number of Transactions (m) & 13.32 & 46.61 & 96.10 & 65.67 & 52.14 & 36.46 & 19.54 & 25.55 & 42.11 & 28.97 \\
Number of Trading Volume (m) & 10,298 & 12,281 & 54,440 & 57,829 & 58,726 & 56,685 & 33,255 & 48,545 & 82,545 & 52,306 \\
\hline
\end{tabular}

* All numbers in US\$.

Source: SAMA (2014), UNCTD (2013), and The World Bank (2015).

The Saudi political system is based on the context of an absolute monarchy, ruled firmly by the Al Saud family. While it states advocacy for fairness and equality, the political establishment is viewed as having some negative implications on the rule of law in the country. Hertog (2010) argues that the Saudi judiciary lacks transparency and suffers from interference from the ruling royal family.

Furthermore, the long-standing social superiority of royal family members and some regions, specifically the region of Najd, over others in the country has been the subject of numerous discussions among social scholars. Since Saudi Arabia is a regional 
society in which people tend to strongly identify with their regional backgrounds, people from Najd are considered to have the highest status in Saudi society after the royals (Niblock \& Malik, 2007). Al-Juhany (2002) notes that all Muftis ${ }^{1}$ and most of the country's religious establishment are from Najd, adding more significance to their social status and cultural influence.

Economically, despite the large size of the Saudi economy, the country remains mostly dependent on oil production, which accounted for about $90 \%$ of the national revenues in the early 2000s (SAMA, 2014). Despite ambitious reforms in the last decade, some obstacles remain that hinder the progress of the Saudi market, notably the heavy intervention of the ponderously bureaucratic government ${ }^{2}$ in running the economy (Al-Hussain, 2009). More importantly, economic exploitation by royals and people from Najd is seen as a major controlling influence (Long, 2005). Indeed, the current ownership structures of Tadawul, where the largest shareholders are government, royalty, and individuals from Najd (See Table 2), further support the argument regarding the dominance of these players in the Saudi market.

It appears then that certain political, social, and administrative elements have a significant influence on the emerging Saudi Arabian context, where royals, people from Najd, and government bureaucrats are the leading forces in the local market.

Table 2 The 10 Major Stock Holders in Tadawul*

\begin{tabular}{lcc}
\hline Name & Ownership value** & Category \\
\hline Public Investment Fund & 108,689 & Government \\
General Organization for Social Insurance & 34,837 & Government \\
Public Pension Fund & 24,264 & Government \\
Al-Waleed Al-Saud & 22,438 & Royalty \\
Sabic & 13,649 & $75 \%$ Government \\
Al-Rajhi Family & 5,611 & From Najd \\
Sultan Al-Saud & 3,545 & Royalty \\
Al-Rajhi Family & 2,398 & From Najd \\
Al-Tayyar Family & 927 & From Najd \\
Al-Rabiah Family & 826 & From Najd \\
\hline
\end{tabular}

* Figures as in July 2014.

** Numbers are in US\$ million.

Source: Al-Eqtisadiah (2014). 


\section{LITERATURE REVIEW}

The relationship between board structure and firm financial performance is more varied and compounded than can be depicted by one of the corporate governance theories. Indeed, scholars have argued in recent years that the lack of systematic evidence regarding this relationship is likely attributed to the reliance on a single theoretical approach (Johnson, Schnatterly, \& Hill, 2013; Nicholson \& Kiel, 2007; Withers, Hillman, \& Cannella, 2012). Thus and in line with recent research, hegemony and agency theories are employed as the theoretical foundation of this paper. These approaches are accompanied by contextual considerations relevant to the Saudi market.

\section{Class Hegemony Theory}

Class hegemony theory suggests that individuals with prestige or status should be invited to join the board. The values and interests of the ruling elites are protected by the elimination or reduction of the influence of other social groups (Davis, Yoo, \& Baker, 2003). Through interlocking directorships with other boards, the board at the focal firm is seen as an instrument with which to maintain and extend the power and status of the ruling elite (Domhoff, 2006). Particularly, Huse (2007) indicates that outside directors with prestige or status can reduce firm risk through horizontal integration (i.e. when some competitors are connected together through interlocking directorates) or vertical coordination (i.e. when suppliers or customers are invited to be board members). Through board interlocking and strength of reputation, these directors can provide access to vital resources with favourable financial performance consequences (Wurthmann, 2014). Nevertheless, class hegemony theory has been criticized for ignoring the changing structure of firm ownership. King and Pearce (2010) argue that, although some individual investors still own a sizable share of company equity, private and public institutional investors have become the leading force in modern markets. Subsequently, exclusive emphasis on the power of high prestige directors highlighted by class hegemony theory may not be fully justified, given the influence of institutional investors, suggesting that other corporate governance theories, especially agency theory, can offer more thorough insight.

\section{Agency Theory}

Agency theory proposes that board members act as representatives of shareholders and are responsible for monitoring the actions of executives (Frankforter, Berman, \& Jones, 2000). Agency theory views directors as a key control mechanism by which to prevent mismanagement and the emergence of principal-agent conflicts (Nicholson \& Kiel, 2007). It assumes that institutional investors in boardrooms improve the board's monitoring mechanisms. The theory particularly emphasizes the role of the directorship 
of public institutional investors in performing the control role based on the presumption that they are impartial and free of favoritism. Indeed, Ryan and Schneider (2003) suggest that, while private institutional investors such as private banks and insurance companies may face potential conflicts of interest, public institutional investors such as public pension funds are virtually free of such conflicts. By assuming an active role on the board, public institutional investors can strengthen the monitoring mechanisms of the board, thereby improving firm financial performance (Withers et al., 2012). Nonetheless, Johnson et al. (2013) argue that exclusive reliance on agency theory ignores the fact that directors' roles are not uni-dimensional. Hence, the inclusion of a theoretical approach, such as class hegemony theory, that recognizes other dimensions, is recommended (Xu \& Meyer, 2013).

\section{Theoretical Considerations Related to Corporate Governance in Emerging Markets}

As clarified previously, most of the relevant literature on corporate governance has been based on advanced market context. Mueller (2006) and Fan et al. (2011) suggest that class hegemony and agency theories have been developed in the context of advanced economies, leaving little or no consideration of the unique social, political, and economic contexts presented in emerging markets; thereby, this paper considers these aspects in order to properly achieve its objectives.

Institutional theory has become the leading theory for studying corporate governance in the context of emerging countries (Hoskisson, Eden, Lau, \& Wright, 2000; Xu \& Meyer, 2013). Institutions such as political, economic, social, and educational entities affect market and company practice, helping to shape the strategic direction of these organizations. Yet in emerging economies, companies are often guided by informal institutions such as influential families and business groups (Peng, 2004). Formal regulatory bodies that regulate corporate governance practices such as transparency of management to shareholders, accounting standards, and board structure are either absent, ineffective, or inefficient. Consequently, companies in emerging markets tend to rely on reputation and trust as substitutes for functioning regulations (Allen, 2005).

An additional consideration is that, as the institutional context in emerging markets makes the enforcement of business contracts more challenging and expensive, concentrated ownership surfaces which frequently reflects the influence of key individuals and families. However, this can result in the development of principalprincipal conflicts, which negatively impact firm financial performance (Young et al., 2008). Furthermore, Peng (2004) suggests that listed firms in emerging markets may 
appoint directors such as government representatives for only symbolic purposes. He argues that public firms are likely to be under pressure to maintain legitimacy and transparency in response to political and public demands. Yet, while these companies may strategically comply with these demands for more independent directors, they will subtly limit the independence of those directors (Millar, Eldomiaty, Choi, \& Hilton, 2005). Similarly, Young et al. (2008) propose that, although some public firms in emerging countries may have endorsed corporate governance codes from developed economies, these codes are often ignored or only partially implemented. Thus, poor implementation of robust corporate governance standards can explain the reduction of market valuation and operating performance among firms in emerging markets (Klapper \& Love, 2004).

As institutions, management practices, and learning processes in emerging countries are improving, Hoskisson et al. (2000) and Xu and Meyer (2013) recommend developing corporate governance theories that have been tested in advanced economies by extending and testing them in the distinctive social, political, and economic contexts of emerging markets. Such an approach could make a significant contribution to the corporate governance literature and would improve corporate governance practices in emerging markets (Kearney, 2012).

\section{HYPOTHESES DEVELOPMENT}

Certain political, sociocultural, and administrative elements have influenced the shaping of Tadawul companies. Indeed, individuals from Najd, Saudi Government Representative Directors (SGRDs), and royals frequently appear to be the leading forces in the Saudi local market. Since theoretical frameworks that empirically examine the relationship between board structure and firm financial performance within the Saudi context are absent, this paper proposes a series of hypotheses to address this void.

According to Domhoff (2006), social elitism is manifested through the activities of a variety of organizations and institutions in a given country. In the Saudi Arabian context, regional status appears to have a significant influence in Saudi society, particularly in the region of Najd. Niblock and Malik (2007) indicate that individuals from Najd dominate the social scenes in Saudi Arabia due to the fact that the royal family also descends from Najd. Moreover, the religious status of Najd individuals, which provides legitimacy to the Saudi ruling family, further enhances their social influence (Al-Juhany, 2002). In addition, it has been argued that people from Najd have taken economic advantage of their privileged social status since the beginning of the Saudi modern state. Long (2005) suggests that occupying most of the senior positions 
in the government ministries and state-owned and partially owned firms has enabled people from Najd to also dominate the business scene in the country.

While acknowledging that individuals from Najd are major players in the Saudi economy, Gamlas (2008) argues that such dominance is due to their genuine success in business rather than reliance on favoritism from royals or the government. He clarifies that people from Najd have been known for their involvement in trade for centuries, suggesting that there are no political or social attributions to their significance in the Saudi business society. Wilson (2012) also notes that Najd traders further advanced their position in the local market by benefiting from the economic boom in Saudi Arabia during the 1970s and onward.

Regardless of the seemingly debatable reason behind their local influence, there is a general agreement among scholars that people from Najd are much more in control over Saudi business activities than any regional group in Saudi Arabia. Taking this into consideration, we suggest that, because they occupy a dominant position in the local economy, Saudi firms can benefit from the networks of outside directors from Najd as coopting forces and mitigators to external threats. Outside directors from Najd could reduce political and legal risk through their personal relationships with politicians and regulators, resulting in laws that are favourable for their firms. The provision of vital resources by these directors through their networking and reputations would, as a result, enhance a firm's financial performance in Saudi Arabia. In keeping with class hegemony theory, views on the ruling elite and the embedded contextual attribution of the value of status and influence in Saudi business and society (Huse 2007; Wilson, 2012; Wurthmann, 2014), this paper proposes the following:

$\mathrm{H}_{1}$ : Outside directors from Najd are positively associated with firm financial performance in Saudi Arabia.

Although the Saudi government is the only public institutional investor in Saudi Arabia, the significance of the presence of SGRDs in boardrooms and the quality of their contribution to board deliberation is a subject of debate. As part of an inefficient public sector, SGRDs have been deemed by some scholars as lacking in flexibility and feasibility to function. For instance, Falgi (2009) suggests that SGRDs are state employees lacking appropriate knowledge of and experience with the private sector. He further criticizes them for giving inadequate time and effort to their board assignments and for being often silent at board meetings. His argument received some support from Al-Hussain (2009), who reported that the Saudi-listed banks with a high level of Saudi government representation recorded the lowest stock return ratios. 
Contrary to that view, SGRDs have been argued to effectively monitor management, protect interests of minority stakeholders and encourage good corporate governance. Al-Majed (2012) asserts that most of the firms in which SGRDs are present are the most profitable of all Tadawul firms. He explains that investors feel safer investing in firms in which SGRDs are present due to the notion that their investment would be protected by the government in times of hardship. Al-Kahtani (2014) adds that, because the state is by far the major shareholder in the market and because governance practices have gradually improved in recent years, it is unfair to regard SGRDs as weak monitors who do not possess an understanding of quality, but rather their positive contribution should be acknowledged.

Having presented both views, this paper adopts the latter for three reasons. First, despite the fact that SGRDs are employees of an inefficient public sector, the suggestion made by Falgi (2009) that they are weak board monitors was based on insufficient data, and was therefore perceived as ineffectual scholarship. Second, while Al-Hussain (2009) reported empirical support of the negative impact of SGRDs on stock return ratios, we suspect that the results have been profoundly influenced by the crisis that hit the Tadawul in 2006. Indeed, the findings of Al-Hussain (2009) included data of Tadawul firms from 2006, and consequently it is appropriate to argue that the data was predetermined and the results suffered from analytical problems. Third, although no previous empirical research suggests SGRDs' positive impact on firm financial performance, a recent study made by Al-Kahtani (2014) indicates their importance to firm value and governance practices in Saudi Arabia. Indeed, the adoption of good governance standards by the Saudi-listed firms in recent years could be explained by the effectiveness of SGRDs in playing the control role. In this context and in line with agency theory (Ryan \& Schneider, 2003; Withers et al., 2012), SGRDs would have a positive effect on the financial performance of the Saudi-listed companies, thus we propose the following:

$\mathrm{H}_{2}$ : SGRDs are positively associated with firm financial performance in Tadawul-listed firms.

Due to the fact that Saudi Arabia is an absolute monarchy, it has been long documented that the members of the Saudi royal family have a major influence in initiating and implementing the Kingdom's laws and regulations (Bray \& Darlow, 2013). Such vast authority and power have led Saudi royals to gain the most prestigious and highest status in Saudi society. In parallel with this, their influence is also derived from their massive fortune. Sabri (2001) suggests that the laissez-fair nature of the 
Saudi economy motivated royals to engage in business activities. More importantly, their involvement in local markets has often been accommodated with privilege and favoritism. Al-Rasheed (2010) emphasizes that royalties in Saudi Arabia have relied heavily rlied on their political and social status to win business contracts. In fact, Wilson (2012) further argues that they often block others from gaining expanding economic influence. As a result, reliance on their status and influence has gained them a monopoly on many of the business activities in the country.

This paper advocates that directorship provides solidity, continuity, and stability among directors with royal status. It is therefore seen as a technique to clear the way for political and economic cohesion among Saudi royals. Indeed, Sabri (2001) indicates that royal members tend to hold their ownership in public firms in large blocks, thereby controlling the boards of these firms. Combined with the Kingdom's weak formal institutions, their concentrated ownership could lead to conflicts between them as controlling shareholders and the minority shareholders, thus resulting in the development of principal-principal conflict. Indeed, Mazaheri (2013) reported that directors with royal status tend to use their influence for personal interest over shareholder interest. Applying institutional and principal-principal theories in this context (Schiehll el al., 2014; Young et al., 2008), outside directors with Saudi royal status could not activate efficient corporate governance practices among firms, in return creating weak governance environments that would reflect negatively on firm financial performance. Hence:

$\mathrm{H}_{3 a}$ : Outside directors with royal status are negatively associated with firm financial performance in Saudi Arabia.

While considering the assertion of the above hypothesis, the presence of royals in boardrooms could be beneficial for firms under the condition that SGRDs are also present. In addition to the sources of riches mentioned previously, Al-Rasheed (2010) suggests that the Saudi royal family has accumulated its fortune over the years from multi-billion-dollar public projects granted by the state to family companies, leading many family members to reach unprecedented levels of wealth. Indeed, scholars have noted that the involvement of Saudi royals in the Saudi economy has been associated with state sponsorship. For instance, Sabri (2001: 20) explains that public contracts have been frequently given to royals 'on the basis of their strong kinship and personal ties to the government officials'. Since government representative directors can provide information, potential access to key public servants, and lend legitimacy to firms (Hillman, Cannella, \& Paetzold, 2000), the presence of SGRDs on the board would 
accordingly lend legitimacy to the firm tendering for lucrative state contracts. Indeed, these directors could be important for companies, not just for their information and potential access, but also for the legitimacy they provide.

In this regard, we expect outside directors with royal status to use SGRDs as a coordinating channel of information and legitimacy. SGRDs would then formalize the power and influence of outside directors with royal status, enabling them to legitimize their political and social advantages to lobby for access to massive government funded projects. Eventually, government funded projects are likely be allocated to the firms with this board cluster, leading to flourishing financial performance. Application of class hegemony and institutional theories (Huse, 2007; Wurthmann, 2014), suggest that having outside directors with royal status along with SGRDs in the boardroom would financially benefit the firm through the provision of the business and administration power of the latter, aligned with the utilization of the influence of the former in relation to government decisions on allocating public projects to the business community for implementation. Therefore, we hypothesize the following:

$\mathrm{H}_{3 \mathrm{~b}}$ : Outside directors with royal status, jointly with SGRDs, are positively associated with firm financial performance in Saudi Arabia.

\section{RESEARCH METHOD}

\section{Data and Sample Selection}

We select Tadawul-listed firms as the data population. These firms follow the rules set by the Capital Market Authority (CMA), Saudi Arabia's securities market regulators, in complying with governance standards. We aim to conduct the first large-scale investigation of the Saudi corporate governance environment and so data are collected to cover all 131 Tadawul firms from 2009 to 2013. This timeframe is chosen to avoid any potential influence of the 2006 crisis and the time period's recentness. Due to access limitation to first-hand data, the data is quantitatively approached and based on secondary, publicly available, and certified ${ }^{3}$ data. Over a period of 10 months, all data is manually extracted from the firms' annual reports, which are obtained from the Tadawul webpage. We use the Al-Jassir (2001) dictionary of Najd genealogies ${ }^{4}$ to identify the regional backgrounds of directors from the region of Najd, where the background of individuals is determined through family name ${ }^{5}$.

\section{Dependent Variable}

We choose Return On Assets (ROA) as the dependent variable. As an accountingbased measure of performance, ROA is historical and thus presents a more backward 
and inward-looking focus. Developed as a reporting mechanism, ROA represents the impact of past successes of board deliberations and is the traditional mainstay of corporate financial performance measures (Hill, Upadhyay, \& Beekun, 2015). Despite the arguments for adjusting income in the ROA calculation to account for implicit interest or indirectly invested capital, Wahlen, Baginski, and Bradshaw (2014) advise that, in all but extreme cases, such adjustment usually results in only minor changes in the analyses of ROA. Hence, we follow the conventional calculation of ROA, through dividing net income by total assets. Furthermore, our justification for the exclusion of market-based measures is due to the fact that they are often subject to forces beyond firm control. This is indeed the case in Saudi Arabia, given the fluctuations in oil prices and geopolitical risks highly influencing the volatilities of the Saudi stock market.

\section{Explanatory Variables}

The key explanatory variables are outside directors from Najd, SGRDs, and outside directors with royal status. These variables are directly obtained from data sources, with no proxies used to compromise the capture of the variables. To demonstrate, outside directors from Najd are recognized through their existence in the data sources as outside directors, in which their genealogies descend from the region of Najd. Similarly, outside directors with royalty status are identified through their mention in the data sources as outside directors who hold the title of 'Prince' with a family name of 'Al Saud'. Lastly, SGRDs are captured through their existence in the data sources as directors who represent Saudi government funds. These variables are measured through the use of the ratio of the total number of outside directors from Najd, SGRDs, and outside directors with royal status, respectively, divided by the total numbers of directors. Ratio measurement is used due to the strength of this technique in its addition of the true zero point and to its common applications in comparable research (Sekaran \& Bougie, 2013).

\section{Control Variables}

To control for confounding influences on firm financial performance, the following are introduced as control variables: firm size, firm age, board size, board meetings, board committees, independent directors, outside directors, and inside directors. As they are standard controls in any research investigating firm financial performance, firm size and firm age are obtained from the data sources through the use of firm total sales and the number of years since the firm's inception, respectively. To respond to a skew towards large values, the paper performed a natural logarithmic transformation on the dollar value of firm sales. Furthermore, board size, board meeting, 
and board committees are included to reflect board effectiveness (De Andres, Azofra, \& Lopez, 2005), firm strategies (Schwartz-Ziv \& Weisbach, 2013), and the magnitude of agency problems (Ghafran \& O'Sullivan, 2013), thereby influencing firm financial performance. Through the data sources of this paper and consistent with corporate governance studies, the total number of values is used as a measure for each of these variables. Finally, independent directors, outside directors, and inside directors are included to account for board classifications, which have long been suggested to be associated with board effectiveness in performing the control, resource, and strategy roles, and by that means impacting firm financial performance (Withers et al., 2012). The identification and measurement of these variables resemble the explanatory variables.

\section{Analytical Approach}

To test the aforementioned hypotheses, we perform a longitudinal hierarchical moderated regression using the specification of Ordinary Least Squares (OLS). Initially, we examine the linear relationships between ROA and the control variables, representing the base model. Subsequently, the explanatory variables are included, indicating the main model. Thereafter, we employ a moderated regression analysis by adding the interactive term intended to test Hypotheses 3b, illustrating model 3. That is ultimately followed by the full model, which combines all of the variables. Accordingly, the full model takes the following form:

$$
Y_{i t}=a+\delta * C_{i t}+\gamma * Z_{i t}+\tau * K_{i t}+\varepsilon_{i t}
$$

$Y=$ The dependent variables.

$i=$ Number of firms.

$t=$ Number of years.

$a=$ Constant.

$C=$ Vector containing the control variables.

$Z=$ Vector containing the explanatory variables.

$K=$ The moderating term.

$\varepsilon=$ The error term.

The terms $\delta, \gamma$, and $\tau$ represent the associated coefficient with the control, explanatory, and the interaction term, respectively.

The selected modeling technique reduces the issue of multicollinearity results from correlations between the main effect variables and the interaction term (Wooldridge, 
2013). Coefficients from the regressions are deployed to assess the models examining the significance of board structure on the Saudi-listed firms' financial performance. To control for time period effects, Huber-White standard errors are used across all of the models. These standard errors are robust to both autocorrelation and heteroskedasticity in longitudinal data (Petersen, 2009).

\section{EMPIRICAL RESULTS}

Table 3 provides the descriptive statistics and correlations for the variables used in this study. With regard to the main variables, the average presence of outside directors from Najd, SGRDs, and outside directors with royal status are 60.28, 9.21, and 3.14\%, respectively. The variations of these averages are respectively $26.33,14.88$, and $7.51 \%$. These figures do indeed support the argument that those players dominate the boardrooms among Tadawul firms. Furthermore, the correlation matrix shows a significant correlation between most of the explanatory and control variables and the dependent variable. While some of the correlations between the various explanatory and control variables are significant, Variance Inflation Factors (VIF) found none over 1.32, which is well below the commonly accepted level of $10^{6}$ (Hair et al., 2010). This suggests that multicollinearity should not be a problem.

Table 3 Descriptive Statistics and Correlation Analysis a

\begin{tabular}{|c|c|c|c|c|c|c|c|c|c|c|c|c|c|c|}
\hline & & Mean & S.D. & 1 & 2 & 3 & 4 & 5 & 6 & 7 & 8 & 9 & 10 & 11 \\
\hline 1 & ROA & $4.76 \%$ & $8.71 \%$ & 1 & & & & & & & & & & \\
\hline 2 & Sales $_{b}$ & 1,093 & 4,293 & $0.211^{*}$ & 1 & & & & & & & & & \\
\hline 3 & Firm Age & 22.25 & 14.49 & $0.332^{*}$ & $0.194^{*}$ & 1 & & & & & & & & \\
\hline 4 & Number of Directors & 8.49 & 1.56 & -0.033 & $0.161^{*}$ & $-0.099 *$ & 1 & & & & & & & \\
\hline 5 & Board Meetings & 5.17 & 1.94 & 0.017 & $0.090 *$ & $0.204 *$ & -0.013 & 1 & & & & & & \\
\hline 6 & Board Committees & 3.04 & 0.80 & $-0.145^{*}$ & $0.140^{*}$ & $-0.235 *$ & $0.179 *$ & $0.085^{*}$ & 1 & & & & & \\
\hline 7 & Independent Directors & $50.80 \%$ & $18.20 \%$ & $-0.117^{*}$ & $-0.102^{*}$ & 0.058 & -0.074 & 0.028 & 0.051 & 1 & & & & \\
\hline 8 & Insider Directors & $11.52 \%$ & $10.57 \%$ & $0.171^{*}$ & -0.058 & $0.112 *$ & -0.066 & $-0.090 *$ & $-0.229 *$ & $-0.224 *$ & 1 & & & \\
\hline 9 & Najd Directors & $60.28 \%$ & $26.33 \%$ & $0.188^{*}$ & $0.138^{*}$ & $0.191^{*}$ & -0.071 & $0.084^{*}$ & 0.015 & $0.118 *$ & -0.063 & 1 & & \\
\hline 10 & SGRDs & $9.21 \%$ & $14.88 \%$ & $0.164^{*}$ & $0.214^{*}$ & $0.139 *$ & $0.131^{*}$ & $0.327 *$ & $0.105^{*}$ & $-0.088 *$ & $-0.169 *$ & $0.278^{*}$ & 1 & \\
\hline 11 & Royal Directors & $3.14 \%$ & $7.51 \%$ & 0.059 & 0.018 & $0.102 *$ & -0.012 & 0.038 & -0.066 & 0 & 0.046 & $-0.248^{*}$ & -0.052 & 1 \\
\hline
\end{tabular}

Table 4 presents the paper's four levels of hierarchical moderated OLS regression results. Model 1 shows a significant relationship between five control variables (firm sales, firm age, number of committees, independent directors, and inside directors) with ROA. In model 2, all indicators of the model fit improved considerably and significantly 
support Hypotheses 1 and 2. However, Hypothesis 3a appears to have no statistically significant support. In model 3, all indicators of the model fit further improved, with Hypotheses $3 \mathrm{~b}$ being significantly supported. This model also reveals a condition of mediation in that SGRDs significantly predict the ROA while controlling for outside directors with royal status with a fairly statistical significance. In the fourth and final model, indicators of the model fit further improved, with all the variables used to represent board structure explaining $22 \%$ of the variance in $\operatorname{ROA}(\mathrm{F}=14.98, \mathrm{p}<0.001)$. Particularly, the five control variables, which proved significant in the base model, are also significant in the full model. More importantly, Hypotheses 1 and $3 \mathrm{~b}$ remain significant and complement their hypothesized direction of relationships. Yet, this cannot be said for Hypotheses 2 and 3a, regarding which SGRDs and outside directors with royal status expectedly lost their statistical significance, given their involvement in the moderation term.

Table 4 Hierarchical regression analysis of board structure impact on ROA

\begin{tabular}{|c|c|c|c|c|c|c|c|c|}
\hline \multirow[b]{2}{*}{ Constant } & \multicolumn{2}{|c|}{ Model 1} & \multicolumn{2}{|c|}{ Model 2} & \multicolumn{2}{|c|}{ Model 3} & \multicolumn{2}{|c|}{ Model 4} \\
\hline & -0.027 & $(0.025)$ & -0.031 & $(0.024)$ & -0.006 & $(0.024)$ & -0.024 & $(0.024)$ \\
\hline \multicolumn{9}{|l|}{ Control Variable: } \\
\hline Firm Size $_{b}$ & $0.010 * * *$ & $(0.002)$ & $0.008^{* * *}$ & $(0.002)$ & $0.009 * * *$ & $(0.002)$ & $0.008 * * *$ & $(0.002)$ \\
\hline Firm Age & $0.002 * * *$ & $(0.000)$ & $0.001^{* * *}$ & $(0.000)$ & $0.002 * * *$ & $(0.000)$ & $0.001^{* * *}$ & $(0.000)$ \\
\hline Board Size & -0.001 & $(0.002)$ & -0.001 & $(0.002)$ & -0.002 & $(0.002)$ & -0.001 & $(0.002)$ \\
\hline Board Meetings & -0.002 & $(0.002)$ & $-0.003 *$ & $(0.002)$ & $-0.003 \dagger$ & $(0.002)$ & -0.003 & $(0.002)$ \\
\hline Board Committees & $-0.007 \dagger$ & $(0.004)$ & $-0.008^{*}$ & $(0.004)$ & $-0.008^{*}$ & $(0.004)$ & $-0.008^{*}$ & $(0.004)$ \\
\hline Independent Directors & $-0.043 *$ & $(0.017)$ & $-0.042 * *$ & $(0.017)$ & $-0.033^{*}$ & $(0.016)$ & $-0.041^{*}$ & $(0.016)$ \\
\hline Inside Directors & $0.090 *$ & $(0.036)$ & $0.109 * *$ & $(0.034)$ & $0.099 *$ & $(0.034)$ & $0.098 * *$ & $(0.034)$ \\
\hline \multicolumn{9}{|l|}{ Explanatory variable: } \\
\hline Najd Directors (H1) & & & $0.043^{* * *}$ & $(0.012)$ & & & $0.041^{* * *}$ & $(0.012)$ \\
\hline SGRDs (H2) & & & $0.069 * *$ & $(0.025)$ & $0.045 \dagger$ & $(0.026)$ & 0.027 & $(0.026)$ \\
\hline Royal Directors (H3a) & & & 0.072 & $(0.045)$ & -0.050 & $(0.042)$ & -0.011 & $(0.042)$ \\
\hline \multicolumn{9}{|l|}{ Interaction term: } \\
\hline SGRDs X Royal Directors (H3b) & & & & & $1.341^{* *}$ & $(0.486)$ & $1.307^{* *}$ & $(0.479)$ \\
\hline $\mathrm{R}^{2}$ & 0.168 & & 0.201 & & 0.208 & & 0.221 & \\
\hline $\operatorname{adj} . R^{2}$ & 0.159 & & 0.188 & & 0.196 & & 0.207 & \\
\hline $\mathrm{F}$ & $17.23^{* * *}$ & & $15.85^{* * *}$ & & $14.07 * * *$ & & $14.98 * * *$ & \\
\hline
\end{tabular}

\section{Robustness Checks}

To ensure the robustness of the OLS regression outcomes, the Shapiro-Wilk (SW) test is conducted across all four models, reporting that the data is normally distributed. As a precaution of a possible influence of the sample size of the data on the test, we plotted Kernel Density Estimation (KDE), which further supported the SW results.

More importantly, a comprehensive process has been followed to manage the risk of endogeneity bias. Firstly, the choice of the dependent variable (ROA) is in line with 
comparable studies (De Andres et al., 2005; Nicholson \& Kiel, 2007; Wurthmann, 2014). Thus, the possibility of reverse causality is controlled by the support of theoretical and empirical arguments, of which firm financial performance is the dependent variable. Secondly, following the recommendations of Wooldridge (2013) on reducing the risk of excluding key variables, we control for the potential endogeneity problem with the utilization of the respective control variables. The selected control variables, all of which are consistent with comparative studies, function to minimize the probability of some other factors outside the scope of the paper influencing the findings. The last process to deal with potential reverse causality is conducted through the inspection of the OLS measurement error regarding whether the explanatory variables are actually exogenous, precise, and reliably measured. To do so, we employ Hausman two-stage least squares test (Rabe-Hesketh \& Skrondal, 2008). Specifically, we suspect the explanatory variable - outside directors from Najd - to be endogenous with other variables that were not included in the models. The suspicion is raised due to our results that show that outside directors from Najd are the most significant determinant that influence ROA. Subsequently, through 'economic intuition' (Wooldridge, 2013: 614), we select two relevant Instrumental Variables (IVs): directors with a large equity share ${ }^{7}$ and directorial interlocks. The intuitive choice of these IVs makes sense, because people from Najd are the largest individual stockholders in Tadawul after the Saudi government (refer to Table 2) and because outside directors from Najd highly populate the boardrooms in Saudi (refer to Table 3). The results of the Hausman test for the first and second stages show that the endogenous repressor is appropriately uncorrelated with the disturbance process, thereby ruling out endogeneity concerns.

\section{DISCUSSION}

As noted in the introduction, this paper goes beyond the conventional and Western developed board theories to further pin down and propose a context-aligned approach to identify board members who actually influence firm financial performance. Gergen (2001) suggests that the pattern of meaning is rooted in the context, with a need to appreciate the significance of where the practice of corporate governance happens. Likewise, Mantere and Ketokivi (2013: 77) emphasize that 'organizational observations follow highly contextualized forms and norms of reasoning'. Hence, alignment of theories developed in advanced markets with consideration for the contextual uniqueness of emerging markets appears vital and more informative (Kearney, 2012; Whetten, 2009). Accordingly, this paper makes its theoretical contributions by aligning class hegemony and agency theories with social, administrative, and political 
considerations embedded within the emerging Saudi Arabian market, proposing that outside directors from Najd, SGRDs, and outside directors with royal status are the main players in the Saudi boards, who also influence firm financial performance. In this regard, four hypothesized relationships have been proposed and empirically tested through this paper (See Table 5).

Table 5 Summary of the Hypotheses and Test Results

\begin{tabular}{clc}
\hline & \multicolumn{1}{c}{ Hypotheses } & Test Results \\
\hline$H_{1}$ & $\begin{array}{l}\text { Outside directors from Najd are positively associated with firm financial } \\
\text { performance in Saudi Arabia. }\end{array}$ & Supported \\
& & SGRDs are positively associated with firm financial performance in \\
$H_{2}$ & Tadawul listed firms. & Supported \\
& $\begin{array}{l}\text { Outside directors with royal status are negatively associated with firm } \\
\text { financial performance in Saudi Arabia. }\end{array}$ & Not supported \\
& $\begin{array}{l}\text { Outside directors with royal status, jointly with SGRDs, are positively } \\
H_{3 b}\end{array}$ & Supported \\
\hline
\end{tabular}

Firstly, we built Hypothesis 1 on the premise that the social aspect of Saudi Arabia is a significant element in which the country is a regional-based society where the region of Najd is the most privileged region in the country by far, influencing local traditions and customs and, more importantly, the business sector in the country. Indeed, our findings demonstrate that over $60 \%$ of the boardrooms in the Saudi listed firms are populated by individuals from Najd, revealing a strong indication of their business dominance. Building on a valid premise aligned with the views of class hegemony theory on the ruling elite (Domhoff, 2006; Wurthmann, 2014), our findings confirm Hypothesis 1, showing a positive relationship between outside directors from Najd and firm financial performance in Tadawul firms. This indicates that boards with a higher presence of outside directors form Najd are more effective in providing resources and access and mitigating external risk, thus creating better financial performance for their firms.

Secondly, because the Saudi government is the solo public institutional investor in Tadawul, holding more than half of its stocks (Al-Eqtisadiah, 2014), classifying SGRDs to represent the administrative paradigm of the Saudi context in boardrooms seems accurate. Informed by agency theory (Withers et al., 2012) with reference to the Saudi context, Hypothesis 2 has been empirically supported, suggesting that SGRDs strengthen the control role of the board. Despite concerns of their bureaucratic and inefficient functioning, our findings demonstrate that SGRDs are effective monitors 
with good contribution to board deliberation, thus reflecting positively on firm financial performance.

Thirdly, the absolute control of the Saudi royal family over the country political affairs appears to underline their involvement in local business. Capitalizing on their political and social status, our results show that some members of the royal family are the leading forces in the Saudi market after the government, making them very influential in the business community. Yet, their direct deliberations as directors are unclear, given their reported scant presence in the Saudi boardrooms. In this regard, previous arguments suggesting that directorships are used as a domain to clear the way for political and economic cohesion among the Saudi royal family seem unpersuasive. Moreover, Hypothesis 3a, which advocates that outside directors with royal status use their influence to oppress the other board members thereby preventing firms to perform constructively, is not supported by our regression. However, the final model did not show an inverse of this. A possible explanation for this outcome is that royals do not necessarily hinder the functionality of the board or promote weak governance practices.

Alternatively, when outside directors with royal status align forces with SGRDs as Hypothesis $3 b$ proposes, the results show that their joint powers positively influence firm financial performance. Informed by class hegemony theory and the Saudi administrative and political context (Huse, 2007; Sabri, 2001), the political influence of royal directors together with the administrative positions of SGRDs appear to influence their companies especially in relation to government decisions on allocating public projects. Hypothesis 3a was not statistically supported, but Hypothesis 3b did signify that royals by themselves do not influence firm financial performance. However, when they are accompanied by SGRDs in the boardroom, a significant shift in their board functioning and approach occurs, which positively impacts firm financial outcomes.

Overall, our findings further enhance the stream of research questioning the adequacy of applying the Anglo-American developed theories without contextual considerations when studying corporate governance in emerging markets. This paper shows that applying only the Anglo-American model of corporate governance is inadequate in the Saudi emerging market because of the different structural and social institutions. Indeed, certain social, administrative, and political factors have been demonstrated to be very influential in determining board structure in an emerging market context. Notably, these factors have a pronounced impact on firm financial performance. Perhaps contextual considerations not only relate to corporate governance studies, but also have an overreaching impact on management, strategy, and business literature. 


\section{Limitations}

This study is not without limitations. It should be noted that the size of the sample might be a cause of concern. While the totality of the market has been achieved, the number of 131 firms is relatively small in comparison with other emerging stock markets. Therefore, it is possible that a sample including more firms may lead to different results. Similarly, restriction to just one country could limit the generalizability of the findings. Just as the argument that research developed within an advance market context may not be applicable to emerging markets, the finding of this study could also be specific to the Saudi context. For example, the findings in relation to outside directors from a particular region with high social, economic, and political status are not applicable for countries where regionalism does not have an influence on political or economic scenes. However, regional status can be substituted by ethnic or religious status as applicable in other emerging market contexts. Thus, with careful consideration in combination with the context of other emerging countries, we consider the chosen sample as representative of emerging markets that share similar contexts with Saudi Arabia (e.g. countries with absolute monarchical or party rule and/or influential social class) and thereby, our findings can be generalizable to different emerging markets. Lastly, while ROA is rigorous and widely used, employing other measures that account for liquidity, solvency, and profitability may present different outcomes.

\section{Future Research}

With the above limitations in mind, the paper offers suggestions for future research. We urge future studies investigating the effect of board structure on firm financial performance - and corporate governance in general - in emerging markets to adopt a more comprehensive research agenda. Bundling conventional theories with contextual consideration would generate informative insights on evaluating the implication of corporate governance in emerging markets.

Furthermore, while the limited knowledge of the relationship between board structure and firm financial performance is 'due to the fact that it is quite difficult for researchers to access and observe how boards of directors work' (Payne et al., 2009: 705), we advocate that qualitative and observational research could produce more insight into how boards actually function. Finally, to enhance the generalizability of our findings to other contexts, future studies need to explore this relationship in other emerging economies. Comparative studies with robust analysis could be of great significance and may lead to the establishment of a new vein of research. 


\section{Practical Implication}

Based on the findings of this study, three implications can be proffered for the practice of corporate governance in emerging economies, particularly in Saudi Arabia. First, it is critical for firms and investors in emerging countries to optimize the recognition of board structure beyond the conventional classifications of independent, outside, and inside directors. Because firms in Saudi Arabia and those within emerging markets generally lack effective corporate governance mechanisms, adjustment for the informal arrangements of local institutions appears crucial. In such a manner, a contextually embedded configuration of board members in emerging markets could yield better financial outcomes for firms and investors. Second, international organizations, like the International Monetary Fund (IMF), that offer consultancy and recommendations to regulators should consider the contextual uniqueness when shedding light on corporate governance practices in emerging markets. This would lead to more accurate and informative assessments and thereby more relevant and viable recommendations. Third, this study further supports the notion that formal institutions in the emerging Saudi market are weak and lack effectiveness. However, relying on the power of informal institutions may not be sustainable. In fact, it could lead to social, economical, and political distraction in the long term. The Saudi government should engage in producing comprehensive reforms that will be fully and promptly implemented based on lessons learnt from countries that have already transitioned from emerging to advanced economies.

\section{CONCLUSION}

This paper explores the impact of board structure and firm financial performance in the context of the emerging Saudi Arabian market. The paper advocates that it is imperative to bundle conventional theories developed in advance markets with contextual considerations when investigating this phenomenon in emerging markets. Our findings show that certain social, political, and administrative factors within the Saudi context determine the structural approach of a board of directors that enhance firm financial performance. The findings also suggest that the absence of functioning formal institutions has led Saudi boardrooms to rely on informal institutions due to their deliverability and effectiveness. Although the sustainability of these institutions as a substitute to formal institutions in emerging markets remains implausible, they will most likely endure as relevant and influential in the foreseeable future. Their powerful influence in boardrooms and generally in corporate governance should be taken into consideration by academia and industry alike. 


\section{NOTES}

1. The Mufti is the head of the religious establishment in Saudi Arabia, which is a title equivalent to the Pope.

2. The Saudi government effectiveness ranks 127 of 189 countries by The World Bank (2015).

3. All the annual reports have been certified by the CMA and one of the Big Four.

4. Al-Jassir is perceived as the most credible and reliable scholar in Najd genealogies. His book “Assembling the Genealogies of the Localized Families in Najd” is considered the most significant book in Najd genealogy (Wail, 2012).

5. In accordance with the local custom, family names indicate the regional background of Saudis.

6. Initially, the correlation matrix shows a large correlation between outside directors and independent directors, reporting $0.83 \%$. This indicates a multicollinearity problem between the two variables. The VIF also shows that outside directors come first in the test table, with a result of 298.27, confirming a multicollinearity problem. Thus, we eliminated outside directors as a control variable, and subsequently the used variables appear to be free of multicollinearity.

7. In line with the CMA guidance, the individual who holds $5 \%$ or more of the firm's total stocks is considered a large investor.

\section{ACKNOWLEDGEMENT}

The author thanks the anonymous reviewers for their invaluable feedback. The author expresses his sincere gratitude to Stephen Barkley from Booz Allen Hamilton Learning and Development, for his support in the editing of this paper.

\section{REFERENCES}

Al-Eqtisadiah. (2014). Markets and Figures: Report on the Largest Shareholders in Tadawul. $\quad$ Retrieved July 22, 2015, from http://www.aleqt.com/2014/07/10/article_865848.html.

Al-Jassir, H. (2001). Assembling the Genealogies of the Localized Families in Najd, 3rd ed. Riyadh: Dar-Alymama Publications.

Al-Juhany, U. (2002). Najd Before the Salafi Reform Movement: Social, Political, and Religious Conditions During the Three Centuries Preceding the Rise of the Saudi State. Reading: Garnet Publishing.

Al-Hussain, A. (2009). Corporate Governance Structure Efficiency and Bank Performance in Saudi Arabia. Phoenix: University of Phoenix. 
Al-Kahtani, F. (2014). Current Board of Directors' Practices in Saudi Corporate Governance: A Case for Reform. in Idowu, S., \& Caliyurt, K. (Eds.) Corporate governance: An international perspective, 299-338. Berlin: Springer-Verlag. http://dx.doi.org/10.1007/978-3-642-45167-6_16

Allen, F. (2005). Corporate Governance in Emerging Economies. Oxford Review of Economic Policy, 21(2), 164-177. http:/dx.doi.org/10.1093/oxrep/gri010

Al-Majed, F. (2012). A Conceptual Framework for Reforming the Corporate Governance of Saudi Publicly Held Companies. Riyadh: SABIC Publications.

Al-Rasheed, M. (2010). A History of Saudi Arabia. Cambridge: Cambridge University Press.

Bray, B., \& Darlow, M. (2013). Ibn Saud: The Desert Warrior Who Created the Kingdom of Saudi Arabia. New York: Skyhorse Publishing.

Daily, M., Dalton, D., \& Cannella, A. (2003). Corporate Governance: Decades of Dialogue and Data. Academy of Management Review, 28(3), 371-382. http://dx.doi.org/10.5465/AMR.2003.10196703

Davis, G., Yoo, M., \& Baker, W. (2003). The Small World of the American Corporate Elite, 1982-2001. Strategic Organization, 1(3), 301-326. http://dx.doi.org/10.1177/14761270030013002

De Andres, P., Azofra, V., \& Lopez, F. (2005). Corporate Boards in OECD Countries: Size, Composition, Functioning and Effectiveness. Corporate Governance: An International Review, 13(2), 197-210. http://dx.doi.org/10.1111/j.14678683.2005.00418.x

Domhoff, G. (2006). Who Rules America? Power and Politics, 5th ed. New York: McGraw Hill.

Falgi, I. (2009). Corporate Governance in Saudi Arabia: A Stakeholder Perspective. Dundee: University of Dundee.

Fan, J., Wei, K., \& Xu, X. (2011). Corporate Finance and Governance in Emerging Markets: A Selective Review and an Agenda for Future Research. Journal of $\begin{array}{lll}\text { Corporate } \quad \text { Finance, 207-214. } & \text { 17(2), }\end{array}$ http://dx.doi.org/10.1016/j.jcorpfin.2010.12.001

Frankforter, S., Berman, S., \& Jones, T. (2000). Boards of Directors and Shark Repellents: Assessing the Value of an Agency Theory Perspective. Journal of Management Studies, 37(3), 321-348. http://dx.doi.org/10.1111/1467-6486.00183 Gamlas, E. (2008). History of Najd. Riyadh: Arab Encyclopedia House.

Gergen, K. (2001). Social Construction in Context. London: Sage Publications. 
Ghafran, C., \& O'Sullivan, N. (2013). The Governance Role of Audit Committees: Reviewing a Aecade of Evidence. International Journal of Management Reviews, 15(4), 381-407. http://dx.doi.org/10.1111/j.1468-2370.2012.00347.x

Hair, J., Tatham, R., Anderson, R., \& Black, W. (2010). Multivariate Data Analysis, 6th ed. New Jersey: Pearson Prentice Hall.

Hertog, S. (2010). Princes, Brokers and Bureaucrats: Oil and the State in Saudi Arabia. New York: Cornell University Press.

Hill, A., Upadhyay, A., \& Beekun, R. (2015). Do Female and Ethnically Diverse Executives Endure Inequity in the CEO Position or Do they Benefit from their Minority Status? An Empirical Examination. Strategic Management Journal, 36(8), 1115-1134. http://dx.doi.org/10.1002/smj.2274

Hillman, A., Cannella, A., \& Paetzold, R. (2000). The Resource Dependence Role of Corporate Directors: Strategic Adaptation of Board Composition in Response to Environmental Change. Journal of Management Studies, 37(2), 235-256. http://dx.doi.org/10.1111/1467-6486.00179

Hoskisson, R., Eden, L., Lau, C., \& Wright, M. (2000). Strategy in Emerging Economies. Academy of Management Journal, 43(3), 249-267. http://dx.doi.org/10.2307/1556394

Huse, M. (2007). Boards, Governance and Value Creation: The Human Side of Corporate Governance. Cambridge: Cambridge University Press.

Huse, M., Hoskisson, R., Zattoni, A., \& Vigano R. (2011). New Perspectives on Board Research: Changing the Research Agenda. Journal of Management \& Governance, 15(1), 5-28. http://dx.doi.org/10.1007/s10997-009-9122-9

Johnson, S., Schnatterly, K., \& Hill, A. (2013). Board Composition Beyond Independence: Social Capital, Human Capital, and Demographics. Journal of Management, 39(1), 232-262. http://dx.doi.org/10.1177/0149206312463938

Judge, W. (2012). The Importance of Considering Context when Developing a Alobal Theory of Corporate Governance. Corporate Governance: An International Review, 20(2), 123-124. http://dx.doi.org/10.1111/j.1467-8683.2011.00901.x

Kearney, C. (2012). Emerging Markets Research: Trends, Issues and Future Directions. Emerging Markets Review, 13(2), 159-183. http://dx.doi.org/10.1016/j.ememar.2012.01.003

King, B., \& Pearce, N. (2010). The Contentiousness of Markets: Politics, Social Movements, and Institutional Change in Markets. Annual Review of Sociology, 36(1), 249-267. http://dx.doi.org/10.1146/annurev.soc.012809.102606

Klapper, L., \& Love, I. (2004). Corporate Governance, Investor Protection, and Performance in Emerging Markets. Journal of Corporate Finance, 10(5), 703-728. 
http://dx.doi.org/10.1016/S0929-1199(03)00046-4

Long, D. (2005). Culture and Customs of Saudi Arabia. Westport: Greenwood Publishing Group.

Marquis, C., \& Raynard, M. (2015). Institutional Strategies in Emerging Markets. The Academy of Management Annals, 9(1), 291-335. http://dx.doi.org/10.1080/19416520.2015.1014661

Mantere, S., \& Ketokivi, M. (2013). Reasoning in Organization Science. Academy of Management Review, 38(1), 70-89. http://dx.doi.org/10.5465/amr.2011.0188

Mazaheri, N. (2013). The Saudi Monarchy and Economic Familism in an Era of Business Environment Reforms. Business and Politics, 15(3), 295-321. http://dx.doi.org/10.1515/bap-2012-0039

Millar, C., Eldomiaty, T., Choi, C., \& Hilton, B. (2005). Corporate Governance and Institutional Transparency in Emerging Markets. Journal of Business Ethics, 59(2), 163-174. http://dx.doi.org/10.1007/s10551-005-3412-1

Mueller, D. (2006). The Anglo Saxon Approach to Corporate Governance and its Applicability to Emerging Markets. Corporate Governance: An International Review, 14(4), 207-219. http://dx.doi.org/10.1111/j.1467-8683.2006.00503.x

Niblock, T., \& Malik, M. (2007). The Political Economy of Saudi Arabia. New York: Routledge.

Nicholson, G., \& Kiel, G. (2007). Can Directors Impact Performance? A Case based Test of Three Theories of Corporate Governance. Corporate Governance: An International Review, 15(4), 585-608. http://dx.doi.org/10.1111/j.14678683.2007.00590.x

Payne, G., Benson, G., \& Finegold, D. (2009). Corporate Board Attributes, Team Effectiveness and Financial Performance. Journal of Management Studies, 46(4), 704-731. http://dx.doi.org/10.1111/j.1467-6486.2008.00819.x

Peng, M. (2004). Outside Directors and Firm Performance During Institutional Transitions. Strategic Management Journal, 25(5), 453-471. http://dx.doi.org/10.1002/smj.390

Petersen, M. (2009). Estimating Standard Errors in Finance Panel Data Sets: Comparing Approaches. Review of Financial Studies, 22(1), 435-480. http://dx.doi.org/10.1093/rfs/hhn053

Rabe-Hesketh, S., \& Skrondal, A. (2008). Multilevel and Longitudinal Modeling Using Stata. Texas: Stata Press.

Ryan, L., \& Schneider, M. (2003). Institutional Investor Power and Heterogeneity Implications for Agency and Stakeholder Theories. Business \& Society, 42(4), 398-429. http://dx.doi.org/10.1177/0007650303260450 
Sabri, S. (2001). The House of Saud in Commerce: A Study of Royal Entrepreneurship in Saudi Arabia. New Delhi: I.S. Publications Pvt. Ltd.

SAMA. (2014). Fiftieth Annual Report - Latest Economic Developments. Retrieved May 11, 2015, from http://www.sama.gov.sa/en-

US/EconomicReports/AnnualReport/5600_R_Annual_En_50_Apx.pdf

Schiehll, E., Ahmadjian, C., \& Filatotchev, I. (2014). National Governance Bundles Perspective: Understanding the Diversity of Corporate Governance Practices at the Firm and Country Levels. Corporate Governance: An International Review, 22(3), 179-184. http://dx.doi.org/10.1111/corg.12067

Schwartz-Ziv, M., \& Weisbach, M. (2013). What Do Boards Really Do? Evidence From Minutes of Board Meetings. Journal of Financial Economics, 108(2), 349-366. http://dx.doi.org/10.1016/j.jfineco.2012.04.011

Sekaran, U., \& Bougie, R. (2013). Research Methods for Business: A Skill Building Approach, 6th ed. Sussex: John Wiley \& Sons.

The World Bank. 2015. The Worldwide Governance Indicators (WGI) Project. Retrieved June 03, 2015, from http://info.worldbank.org/governance/wgi/index.aspx\#countryReports

UNCTD. (2013). Investment Country Profile: Saudi Arabia. Geneva: United Nations Conference on Trade and Development.

Wahlen, J., Baginski, S., \& Bradshaw, M. (2014). Financial Reporting, Financial Statement Analysis and Valuation. Boston: Cengage Learning.

Wail, M. (2012). Witness of This Ear, 6th ed. Riyadh: Dar Twiq Publication.

Whetten, D. (2009). An Examination of the Interface Between Context and Theory Applied to the Study of Chinese Organizations. Management and Organization Review, 5(1), 29-55. http://dx.doi.org/10.1111/j.1740-8784.2008.00132.x

Wilson, R. (2012). Economic Development in Saudi Arabia. New York: Routledge.

Withers, M., Hillman, A., \& Cannella, A. (2012). A ultidisciplinary Review of the Director Selection Literature. Journal of Management, 38(1), 243-277. http://dx.doi.org/10.1177/0149206311428671

Wooldridge, J. (2013). Introductory Econometrics: A Modern Approach, 5th ed. Mason: Cengage Learning

Wurthmann, K. (2014). Service on a Stigmatized Board, Social Capital, and Change in Number of Directorships. Journal of Management Studies, 51(5), 814-841. http://dx.doi.org/10.1111/joms.12087

Xu, D., \& Meyer, K. (2013). Linking Theory and Context: Strategy Research in Emerging Economies After Wright et al. 2005. Journal of Management Studies, 50(7), 1322-1346. http://dx.doi.org/10.1111/j.1467-6486.2012.01051.x 
Young, M., Peng, M., Ahlstrom, D., Bruton, G., \& Jiang, Y. (2008). Corporate Governance in Emerging Economies: A Review of the Principal-Principal Perspective. Journal of Management Studies, 45(1), 196-220. http://dx.doi.org/10.1111/j.1467-6486.2007.00752.x 